\title{
Glikokortykosteroidy a zaburzenia metabolizmu glukozy
}

\author{
Glucocortycosteroids and disturbances of glucose metabolism
}

\section{STRESZCZENIE}

Glikokortykosteroidy (GS) należą do grupy hormonów steroidowych, które u ludzi regulują szerokie spektrum reakcji fizjologicznych niezbędnych do życia, takich jak wzrost, reprodukcja, reakcje immunologiczne i zapalne. Syntetyczne GS są powszechnie stosowanymi lekami w chorobach zapalnych, autoimmunologicznych i limfoproliferacyjnych. Steroidoterapia wiąże się jednak z występowaniem wielu działań niepożądanych, w tym zaburzeń metabolicznych. Jednym $z$ nich jest cukrzyca posteroidowa. Za efekt diabetogenny GS odpowiada kilka mechanizmów, takich jak antagonistyczne działanie w stosunku do insuliny, wzrost insulinooporności na poziomie wątroby, mięśni szkieletowych i tkanki tłuszczowej, upośledzenie zdolności sekrecyjnych komórki beta, wpływ na komórki alfa i wzrost wydzielania glukagonu, zmniejszenie efektu inkretynowego czy stymulowanie gromadzenia się tłuszczu trzewnego. Zaburzenia gospodarki węglowodanowej wywołane działaniem GS charakteryzują się prawidłowym lub nieznacznie podwyższonym stężeniem glukozy na czczo i istotnym wzrostem glikemii poposiłkowych, zwłaszcza w godzinach popołudnio-

Adres do korespondencji:

dr n. med. Dorota Pisarczyk-Wiza

Katedra i Klinika Chorób Wewnętrznych i Diabetologii

Uniwersytet Medyczny im. Karola Marcinkowskiego w Poznaniu

Szpital Miejski im. Franciszka Raszei

ul. Mickiewicza 2, 60-834 Poznań

tel. +48 (61) 22453 70, faks: +48 (61) 8474579

e-mail:wizus@wp.pl

Diabetologia Kliniczna 2015, tom 4, 3, 110-116

DOI: 10.5603/DK.2015.0010

Copyright (C) 2015 Via Medica

Nadesłano: 15.04.2015

Przyjęto do druku: 13.05.2015 wych i wieczornych. Wysiłki terapeutyczne powinny zatem być ukierunkowane na zwalczanie tych właśnie zaburzeń. (Diabet. Klin. 2015; 4, 3: 110-116)

Słowa kluczowe: glikokortykosteroidy, metabolizm glukozy, cukrzyca

\section{ABSTRACT}

Glucocorticosteroids (GS) are a group of steroid hormones that regulate human physiological reactions of a wide spectrum of the necessities of life, such as growth, reproduction, immune and inflammatory reactions. Synthetic corticosteroids are commonly used drugs in inflammatory, autoimmune and lymphoproliferative diseases. However, steroids therapy is associated with the occurrence of many side effects, including metabolic disturbances. One of them is poststeroid diabetes. Several mechanisms are responsible for diabetogenic effect of GS, such as antagonistic action against insulin, increase of insulin resistance at the level of the liver, skeletal muscle and adipose tissue, impaired secretory capacity of the beta cells, effects on alpha cells leading to increase glucagon secretion, decreased the incretin phenomenon and gathering visceral fat. Disturbances in glucose metabolism induced by the action of GS are characterized by normal or slightly elevated fasting glucose and markedly postprandial glucose increase, especially in the afternoon and evening. Therapeutic efforts should therefore be directed at combating these particular disorders. (Diabet. Klin. 2015; 4, 3: 110-116)

Key words: glucocorticosteroids, glucose metabolism, diabetes 


\section{Wstęp}

Glikokortykosteroidy (GS) należą do bardzo skutecznych i powszechnie przepisywanych leków przeciwzapalnych. Aktywność przeciwzapalną kortyzolu odkryto już w 1948 roku, a do praktyki klinicznej GS zostały wprowadzone 2 lata później - w 1950 roku. W tym też roku Kendall, Reichstein i Hench otrzymali Nagrodę Nobla w dziedzinie fizjologii i medycyny za odkrycie budowy i biologicznych funkcji hormonów wydzielanych przez nadnercza u ssaków [1]. Prace tych autorów pozwoliły na dokładne scharakteryzowanie hormonów produkowanych przez korę nadnerczy, a następnie ich powszechne wykorzystanie w wielu gałęziach medycyny.

Glikokortykosteroidy należą do grupy hormonów steroidowych, które u ludzi regulują szerokie spektrum reakcji fizjologicznych niezbędnych do życia, takich jak wzrost, reprodukcja, reakcje immunologiczne i zapalne. Odgrywają ważną rolę w utrzymaniu podstawowej homeostazy organizmu człowieka, regulując między innymi metabolizm węglowodanów, tłuszczów i białek oraz gospodarkę wodno-elektrolitową. Biorą udział w odpowiedzi organizmu na stres fizyczny i psychiczny. Wpływają na zmiany nastroju i zachowania, modyfikują apetyt, temperaturę ciała, percepcję bólową i funkcje neuroendokrynne. Oddziałują na funkcjonowanie ośrodkowego układu nerwowego i układu sercowo-naczyniowego. Odpowiadają za rozmieszczenie tkanki tłuszczowej i metabolizm kości [2, 3]. Syntetyczne GS są jednymi z najczęściej stosowanych leków zalecanych w wielu chorobach zapalnych, autoimmunologicznych i limfoproliferacyjnych, zarówno w stanach ostrych, jak i przewlekłych [4, 5].

Stosowanie GS w praktyce klinicznej wiąże się jednak z występowaniem wielu, zarówno narządowych, jak i ogólnoustrojowych działań niepożądanych, w tym szeregu niekorzystnych zaburzeń metabolicznych [3, 6-8]. Hormony te powodują otyłość brzuszną, oporność na insulinę, zaburzenia gospodarki lipidowej i nadciśnienie tętnicze. Glikokortykosteroidy zwiększają również ryzyko wystąpienia cukrzycy i w konsekwencji wpływają na rozwój chorób układu sercowo-naczyniowego [9]. Są lekami o silnym działaniu diabetogennym. Termin steroid-induced diabetes użyty został po raz pierwszy przez Ingle w 1940 roku do opisania hiperglikemii i glukozurii u szczurów otrzymujących hormony steroidowe [10]. Według aktualnie obowiązującej klasyfikacji cukrzyca rozpoznana w trakcie lub po terapii GS powinna być zaliczana do grupy innych określonych typów cukrzycy i traktowana jako cukrzyca wtórna, polekowa [11]. Zastosowanie steroidoterapii u osób z wcześniej rozpoznaną cukrzycą powoduje zazwyczaj istotne pogorszenie wyrównania metabolicznego choroby [12].

\section{Ryzyko rozwoju cukrzycy w przebiegu steroidoterapii}

Ryzyko rozwoju zaburzeń gospodarki węglowodanowej w przebiegu terapii syntetycznymi GS jest trudne do oszacowania. Trudności te wynikają z faktu dużej różnorodności preparatów steroidowych, konieczności stosowania bardzo indywidualnych dawek hormonów w zależności od odmiennych standardów leczenia w konkretnych jednostkach chorobowych, czasu ekspozycji i wrażliwości pacjenta na lek, jak również drogi podania GS. Równocześnie należy podkreślić bardzo różną skłonność osobniczą poszczególnych pacjentów do rozwoju zaburzeń gospodarki węglowodanowej. Może ona zależeć, z jednej strony, od czynników genetycznych, determinujących między innymi wydolność sekrecyjną komórek beta wysp trzustki, z drugiej zaś, od czynników środowiskowych, takich jak styl życia, rodzaj stosowanej diety czy aktywności fizycznej. Wykazano również, że różna wrażliwość receptora GS na hormony steroidowe, uwarunkowana między innymi przez polimorfizmy genu receptora GS może mieć istotny, promujący lub hamujący wpływ na występowanie czynników ryzyka cukrzycy, takich jak otyłość, hiperinsulinemia, insulinooporność, dyslipidemia czy nadciśnienie tętnicze. Opisano polimorfizmy N363S oraz Bcll, które powodują zwiększenie wrażliwości receptora na GS i są związane z niekorzystnym profilem metabolicznym [13, 14]. Z kolei polimorfizmy ER22/E23K i A3669G wiążą się ze wzrostem oporności receptora na działanie tych hormonów i wydają się chronić przed rozwojem zaburzeń metabolicznych [15, 16]. Ryzyko rozwoju zaburzeń gospodarki węglowodanowej w przebiegu leczenia GS mogą zwiększać ograniczenia aktywności ruchowej spowodowane chorobą i stosowanie innych leków diabetogennych. Udział klasycznych czynników ryzyka cukrzycy, takich jak obciążenie rodzinne czy otyłość, w rozwoju cukrzycy posteroidowej pozostaje ciągle niejednoznaczny [17-20]. Danych dotyczących częstości występowania cukrzycy posteroidowej jest niewiele, dotyczą one różnych populacji pacjentów i często obejmują stosunkowo krótki okres obserwacji. Dlatego w dostępnej literaturze istnieje duża rozbieżność w tym zakresie. Według różnych danych cukrzycę posteroidową rozpoznaje się u 1,5-47\% pacjentów leczonych GS [21-24]. Większość badań oceniających efekt działania hormonów steroidowych analizuje tylko wartości glikemii na czczo, mimo że hormony te wpływają przede wszystkim na glikemie w ciągu dnia, głównie poposiłkowe. Dlatego też prawdopodobnie dane dotyczące częstości występowania zaburzeń gospodarki węglowodanowej w przebiegu steroidoterapii są niedoszacowane.

Doustne leczenie GS wiąże się ze zwiększonym ryzykiem rozwoju cukrzycy nawet do 36\% (OR 1,36; 
95\% Cl 1,10-1,69) [25]. Względne ryzyko rozwoju hiperglikemii wymagającej leczenia wynosi 2,23 (OR 2,23; 95\% Cl 1,92-2,59) [26]. Zależność tą, na podobnym poziomie, potwierdzono w przypadku osób w wieku podeszłym, powyżej 65. roku życia (OR 2,31; $95 \% \mathrm{Cl}$ 2,11-2,54) [27]. Stopień zagrożenia cukrzycą wzrasta wraz ze wzrostem dziennej dawki GS i w przeliczeniu na $1 \mathrm{mg}$ hydrokortyzonu wynosi ono 1,77 dla dawek do 39 mg/d., do 10,34 dla dawek powyżej 120 mg/d. [26]. U pacjentów z reumatoidalnym zapaleniem stawów i chorobami nerek wymagających steroidoterapii częstość występowania cukrzycy wynosi 20-40\%, a niezależnymi czynnikami ryzyka jej wystąpienia są starszy wiek i większa masa ciała [28, 29].

Dane dotyczące wpływu wziewnej steroidoterapii na rozwój cukrzycy są niejednoznaczne, wręcz sprzeczne. W około 5-letniej obserwacji pacjentów z astmą i przewlekłą obturacyjną chorobą płuc leczonych wziewnymi GS wykazano wzrost ryzyka rozwoju cukrzycy o $34 \%$ (RR 1,34; 95\% Cl 1,29-1,39). Efekt ten był zależny od dawki i ryzyko cukrzycy było najwyższe przy najwyższych dawkach inhalowanych hormonów, odpowiadających $1000 \mu \mathrm{g}$ lub więcej flutykazonu na dzień (RR 1,64; 95\% Cl 1,52-1,76) [30]. Z kolei w retrospektywnej analizie 26 randomizowanych badań u pacjentów powyżej 4. Roku życia z astmą oskrzelową i przewlekłą obturacyjną chorobą płuc leczenie wziewnymi kortykosteroidami nie powodowało wzrostu ryzyka cukrzycy [31].

Związek między miejscowym stosowaniem kortykosteroidów (np. w wielu chorobach skóry) a ryzykiem rozwoju cukrzycy jest nadal przedmiotem badań. Analiza danych z niderlandzkiego Systemu PHARMO Record Linkage wykazała, że miejscowe stosowanie GS wiązało się z 1,24-krotnie większym ryzykiem wystąpienia cukrzycy (HR 1,24; 95\% Cl 1,11-1,40). Ryzyko to wzrastało do 1,32 (95\% Cl 1,14-1,54) przy długotrwałym (> 180 dni) miejscowym stosowaniu steroidów, a do 1,44 przy zwiększeniu dawki stosowanej miejscowo $(95 \% \mathrm{Cl}$ 1,21-1,72) [32].

Glikokortykosteroidy są stosunkowo często stosowane w postaci iniekcji dostawowych w terapii chorób zwyrodnieniowych i zapalnych stawów. Większość analiz dotyczących efektu dostawowego podawania GS skupia się na działaniu miejscowym tych leków, podkreślając niewielki ich wpływ ogólnoustrojowy. Brakuje miarodajnych danych na temat związku między dostawowym podawaniem GS a ryzykiem rozwoju cukrzycy. Być może spowodowane jest to krótką i najczęściej jednorazową ekspozycją pacjenta na lek i brakiem długoterminowej obserwacji tej grupy chorych. W populacji pacjentów z idiopatycznym młodzieńczym zapaleniem stawów dostawowe iniekcje GS stanowią istotną część terapii.
Działania niepożądane nawet przy stosunkowo częstym dostawowym podawaniu steroidów występują rzadko i nie zanotowano wśród nich cukrzycy [33].

Pomimo jednoznacznych danych, że terapia GS ma wyraźny wpływ na hiperglikemię nadal słabo scharakteryzowane są czynniki ryzyka rozwoju, przebieg czy występowanie przewlekłych powikłań w przebiegu cukrzycy posteroidowej. Dotychczasowe dane wskazują, że czas trwania leczenia GS, ich dawka, pochodzenie etniczne pacjentów, wiek, wskaźnik masy ciała i choroby dodatkowe mogą być czynnikami ryzyka rozwoju cukrzycy posteroidowej [34-38]. Badania biorców przeszczepów wykazały, że częstość występowania cukrzycy zwiększa się wraz z dawką GS i zaburzenia gospodarki węglowodanowej są rozpoznawane często po zwiększeniu dawki leku w trakcie epizodu odrzucenia przeszczepionego narządu [39].

\section{Efekt diabetogenny glikokortykosteroidów}

Za rozwój i zaburzenia gospodarki węglowodanowej w przebiegu terapii GS odpowiada kilka mechanizmów.

1. Glikokortykosteroidy są hormonami o działaniu antagonistycznym do insuliny, a efekt ten ujawnia się szczególnie w takich sytuacjach klinicznych, jak głód czy stres, zwłaszcza u osób z towarzyszącym względnym lub bezwzględnym niedoborem insuliny. Leki te działają synergistycznie z innymi hormonami kontrregulacyjnymi. Potencjalizują i przedłużają efekt działania katecholamin, glukagonu i hormonu wzrostu, wpływając na wiele kluczowych procesów metabolicznych.

2. Glikokortykosteroidy powodują wzrost insulinooporności na poziomie wątroby, mięśni szkieletowych i tkanki tłuszczowej. Leczenie dużymi dawkami GS powoduje przede wszystkim wzrost stężenia glukozy we krwi poprzez nasilenie wątrobowej glukoneogenezy, w wyniku aktywacji enzymów glukozo-6-fosfatazy i karboksykinazy fosfoenolopirogronianowej oraz glikogenolizy, na drodze pośredniej, poprzez potencjalizację działania glukagonu. Pod wpływem GS, w wyniku nasilenia katabolizmu białek i lipolizy, zwiększa się uwalnianie substratów dla glukoneogenezy z tkanek obwodowych: aminokwasów z mięśni, glicerolu z tkanki tłuszczowej $[8,40]$. Konsekwencją działania lipolitycznego hormonów steroidowych jest również uwolnienie wolnych kwasów tłuszczowych, co z kolei zmniejsza wrażliwość na działanie insuliny w obrębie wątroby i mięśni szkieletowych. Glikokortykosteroidy zmniejszają ekspresję receptorów insulinowych i hamują obwodowy wychwyt glukozy przez mięśnie oraz adipocyty. 
3. Glikokortykosteroidy wpływają na funkcje komórek beta i alfa wysp Langerhansa. W ostatnich latach wykazano, że hiperglikemia wywołana przez GS jest konsekwencją nie tylko insulinooporności, ale również istotnego zaburzenia funkcji komórek wysp trzustkowych [41, 42]. Hormony te upośledzają zdolności sekrecyjne komórki beta. W badaniach in vitro wykazano, że GS hamują wydzielanie insuliny na drodze kilku mechanizmów. Leki te zmniejszają pobieranie i utlenianie niektórych metabolitów, w tym glukozy, zmniejszają depolaryzację błony komórkowej, co ogranicza napływ wapnia do wnętrza komórki beta i jego skuteczny udział w procesie sekrecji, regulują funkcję układu parasympatycznego $[43,44]$. Ponadto GS wydają się promować apoptozę komórek beta [45]. Zarówno w badaniach in vitro, jak i in vivo, zarówno na modelu zwierzęcym, jak i na modelu ludzkim wykazano, że jednorazowa duża dawka hormonu steroidowego (hydrokortyzon lub prednizolon) zmniejsza istotnie sekrecję insuliny $[41,46,47]$. Jednak w wyniku długotrwałego podawania GS upośledzenie czynności komórek beta może być maskowane w pewnym stopniu przez hiperinsulinemię, kompensującą obwodową insulinooporność [42]. Oprócz wpływu na funkcję komórek beta GS oddziałują również na funkcję komórek alfa wysp Langerhansa. Zwiększają sekrecję glukagonu na czczo i po posiłku białkowym, co zaburza homeostazę glukozy. Pod ich wpływem wzrasta wątrobowa produkcja glukozy powodująca hiperglikemię [48].

4. Glikokortykosteroidy wpływają na efekt inkretynowy. W badaniach przeprowadzonych na modelu zwierzęcym wykazano, że leczenie GS powodowało zmniejszenie stabilności mRNA genu preproglukagonu, prekursora glukagonopodobnego peptydu-1 (GLP-1, glucagon like peptide-1), co wpływało na jego stężenie [49]. Niewiele jest badań w tym zakresie przeprowadzonych u ludzi, a wyniki są niejednoznaczne. Część autorów potwierdza wpływ hormonów steroidowych na stężenie GLP-1 u młodych osób bez cukrzycy, z kolei inni takiej zależności nie wykazali [50-52]. Wydaje się, że leczenie GS nie tyle wpływa na stężenie GLP-1, ile osłabia insulinotropowe działanie tego hormonu inkretynowego i zmniejsza zależną od glukozy sekrecję insuliny [53]. Należy przeprowadzić dalsze analizy, aby zbadać, czy zjawisko to jest wynikiem bezpośredniego wpływu hormonów steroidowych na komórkę beta, czy pośrednim efektem ogólnoustrojowych zaburzeń spowodowanych stosowaniem GS, takich jak hiperglikemia czy insulinooprność [54].
5. Glikokortykosteroidy stymulują gromadzenie się tłuszczu trzewnego. Wpływają na preadipocyty, przyspieszając ich różnicowanie do adipocytów. Regulują też ekspresję genów dojrzałych komórek tłuszczowych, sprzyjając ich przerostowi i akumulacji lipidów [55, 56].

W wielu badaniach analizujących efekt działania GS stosowano duże dawki hormonów, które powodowały rozwój zaburzeń gospodarki węglowodanowej u pacjentów bez rozpoznanej dotychczas cukrzycy lub istotne pogorszenie wyrównania metabolicznego u chorych z jawną cukrzycą. Jednak w praktyce klinicznej pacjenci często stosują niskie dawki GS, chociażby $\mathrm{w}$ ramach leczenia podtrzymującego $\mathrm{w}$ wielu chorobach. Przez długi czas uważano, że niskie dawki (odpowiedniki $<7,5 \mathrm{mg}$ prednizolonu dziennie) są metabolicznie bezpieczne. Ostatnio jednak wykazano, że także niskie dawki GS powodują wzrost stężenia glukozy po posiłku [52]. Ponadto nawet niska dawka GS upośledza hamujący wpływ insuliny na wątrobową produkcję glukozy oraz lipolizę w tkance tłuszczowej u osób zdrowych i może wpływać na rozwój zaburzeń gospodarki węglowodanowej [40]. Z kolei analiza sekrecji insuliny, stężenia peptydu C i stężenia glukozy w trzech badanych grupach (u chorych na cukrzycę typu 2, w populacji zwiększonego ryzyka zachorowania na cukrzycę oraz u osób z prawidłową tolerancją glukozy) przed i po 3 dniach po podaniu 20 mg prednizonu nie wykazała dla stanu na czczo jakichkolwiek istotnych różnic. Krótkotrwałe zastosowanie średniej dawki prednizonu powodowało jednak hiperglikemię poposiłkową u chorych na cukrzycę typu 2 i u osób ze stanem przedcukrzycowym, od południa do północy, z powodu supresji wydzielania insuliny. Efekt ten zanikał w godzinach nocnych. Supresja wydzielania insuliny była szczególnie widoczna u pacjentów z cukrzycą i występowała już od godzin porannych [57].

Podawanie GS dostawowo u pacjentów z zaburzeniami gospodarki węglowodanowej wiąże się najczęściej z pogorszeniem kontroli cukrzycy. Dwa prospektywne badania oceniały wpływ na kontrolę glikemii pojedynczego wstrzyknięcia GS do stawu kolanowego u chorych z dobrze wyrównaną metabolicznie cukrzycą typu $2\left(\mathrm{HbA}_{1 \mathrm{c}}<7,0 \%\right)$. W pierwszym badaniu 9 pacjentów otrzymało iniekcje 50 mg metyloprednizolonu. U 7 badanych nastąpił wzrost glikemii we krwi w stosunku do wyjściowego stężenia o ponad 2 odchylenia standardowe. Obserwowano wzrost stężenia glukozy powyżej 300 mg/dl, ze szczytem pomiędzy 5. a 84. godziną po iniekcji leku. Efekt hiperglikemii utrzymywał się przez 2-3 dni [58]. W drugim badaniu 6 chorych na cukrzycę otrzymało iniekcję $1 \mathrm{ml}$ betametazonu do stawu kolanowego, co spowodowało u wszystkich 
badanych wzrost stężenia glukozy we krwi do wartości 251-430 mg/dl, ze szczytem po 6 godzinach od podania leku. Nie wykazano zmian w stężeniu fruktozaminy [59]. Z kolei w badaniu oceniającym efekt podania $35 \mathrm{mg}$ metyloprednizolonu do stawu barkowego chorym na cukrzycę typu $2\left(\mathrm{HbA}_{1 \mathrm{c}}=7,6 \%\right)$ w ciągu 2 tygodni po iniekcji nie wykazano istotnych zmian w zakresie średniej glikemii i stężenia fruktozaminy [60]. Wyniki innego retrospektywnego badania, w którym chorzy na cukrzycę otrzymywali 3 iniekcje 3,75 mg kortywazolu (odpowiednik $50 \mathrm{mg}$ metyloprednizolonu) co 3 dni do stawu barkowego wykazały wzrost glikemii poposiłkowych od wyjściowego stężenia $170 \pm 60 \mathrm{mg} / \mathrm{dl}$ przed podaniem leku do $258 \pm 100 \mathrm{mg} / \mathrm{dl} \mathrm{w} 1$. dniu i $252 \pm 87 \mathrm{mg} / \mathrm{dl}$ w 7. dniu obserwacji. Wartości glikemii na czczo nie uległy istotnym zmianom [61].

Wpływ podania syntetycznych GS do przestrzeni zewnątrzoponowej na stężenie glukozy we krwi w przebiegu leczenia radikulopatii jest różny. W większości badań opisano przejściowy istotny wzrost stężenia glukozy we krwi i powrót glikemii do wartości prawidłowych po 2-3 dniach po iniekcji [61-63].

\section{Leczenie cukrzycy posteroidowej}

Aktualnie brakuje oficjalnych i jednoznacznych zaleceń dotyczących postępowania z pacjentami leczonymi GS, z zaburzeniami gospodarki węglowodanowej i bez nich. Ze względu na brak randomizowanych badań klinicznych obejmujących tę populację chorych zasady postępowania oparte są raczej na doświadczeniach i opiniach ekspertów.

Przeprowadzono kilka badań interwencyjnych u zdrowych ochotników, które miały na celu ocenę możliwości zapobiegania czy też leczenia hiperglikemii wywołanej GS. Wykazano w nich korzystny efekt głównie w przypadku troglitazonu, jednak lek ten od dawna jest wycofany z praktyki klinicznej, ponieważ powodował istotne działania niepożądane [64, 65].

Biorąc pod uwagę mechanizmy patogenetyczne rozwoju zaburzeń gospodarki węglowodanowej w trakcie stosowania GS celowe wydaje się leczenie metforminą, przy braku przeciwwskazań do jej stosowania. Terapia ta jest jednak często niewystarczająca. U pacjentów z małą rezerwą sekrecyjną komórek beta zalecana powinna być insulina. Glikokortykosteroidy powodują przede wszystkim poposiłkowy wzrost glikemii, obserwowany w ciągu dnia, dlatego rekomendowane są preparaty krótkodziałające insuliny lub szybkodziałające analogi insuliny [66]. Stosowanie preparatów steroidowych o pośrednim czasie działania w godzinach porannych (prednizon, prednizolon, metylprednizolon) powoduje zanik fizjologicznego profilu insulinowrażliwości. Dlatego należy zwrócić szczególną uwagę na konieczność modyfikacji dawek i zmianę dotychczasowych proporcji ilości podawanej insuliny w poszczególnych porach dnia oraz ich istotne zwiększenie w godzinach południowych, popołudniowych i wieczornych. Doświadczenia własne wskazują na celowość edukacji pacjentów leczonych zmiennymi dawkami GS w zakresie intensywnej czynnościowej insulinoterapii. Metoda ta umożliwia chorym adaptację dawki insuliny okołoposiłkowej w zależności od aktualnego stężenia glukozy, wielkości posiłku i wysiłku fizycznego. Istotne jest również dostosowanie dawek tak zwanej insuliny bazalnej (preparaty insuliny o przedłużonym czasie działania, długodziałające analogii insuliny lub wlew podstawowy) do zmieniającego się zapotrzebowania na insulinę. Steroidoterapia często wymaga zmiany proporcji dawek insuliny bazowej, z przewagą dziennej w związku z silną supresją wydzielania endogennej insuliny już od rana. Należy podkreślić, że leczenie syntetycznymi GS wiąże się zazwyczaj z istotnym wzrostem zapotrzebowania na insulinę, które nierzadko przekracza 1 j./kg mc./d. i każda zmiana dawki hormonów wymaga modyfikacji dawek insuliny. Jeżeli u osób leczonych GS pojawią się znaczna hiperglikemia, cukromocz i acetonuria lub rozwinie się cukrzycowa kwasica ketonowa należy rozpocząć leczenie insuliną podawaną dożylnie według ogólnie przyjętych zasad terapii stanów ostrych w cukrzycy.

Duże nadzieje wiąże się ze stosowaniem analogów GLP-1 w leczeniu hiperglikemii wywołanej przez GS [67-69]. Bardzo interesujące wydają się próby zastosowania tej grupy leków inkretynowych w prewencji zaburzeń tolerancji glukozy u osób przyjmujących GS. Wykazano, że wlew eksenatydu zapobiegał dysfunkcji komórek wysp trzustkowych i hiperglikemii wywołanej krótkoterminowym podaniem GS [62]. Pojawiły się również doniesienia o korzystnym efekcie stosowania inhibitorów dipeptydylopeptydazy 4 (DPP-4) w cukrzycy posteroidowej [70, 71].

Zaburzenia gospodarki węglowodanowej w przebiegu terapii GS, ze względu na powszechne stosowanie tych leków, występują stosunkowo często, jednak nie zawsze są prawidłowo diagnozowane i leczone. Istnieje duża potrzeba zainteresowania tym problemem nie tylko lekarzy diabetologów, ale może przede wszystkim lekarzy rodzinnych i specjalistów innych dziedzin, którzy w swojej codziennej praktyce powszechnie stosują terapię steroidami, ale niekoniecznie monitorują ich działania niepożądane. Pacjenci leczeni GS lub innymi lekami diabetogennymi powinni być zakwalifikowani do grup ryzyka cukrzycy, co nakłada na lekarza obowiązek prowadzenia badań przesiewowych w kierunku zaburzeń gospodarki węglowodanowej. 
Rutynowa kontrola glikemii powinna być zalecana zarówno przed włączeniem steroidoterapii, jak i w trakcie stosowania tej grupy leków. Jest to szczególnie istotne przy długotrwałym leczeniu GS, kiedy kontrola stężenia glukozy powinna być przeprowadzona po rozpoczęciu steroidoterapii, po miesiącu leczenia, a następnie co 3 miesiące [72]. Należy podkreślić, że powinna ona dotyczyć nie tylko glikemii na czczo, ale również glikemii poposiłkowych.

Dotychczasowa wiedza na temat cukrzycy posteroidowej i doświadczenia własne wskazują, że należy opracować standardy postępowania w zakresie rozpoznawania i monitorowania zaburzeń gospodarki węglowodanowej u pacjentów przyjmujących glikokrtykosteroidy oraz schematy ich leczenia.

\section{PIŚMIENNICTWO}

1. Raju T.N. The Nobel chronicles. 1950: Edward Calvin Kendall (1886-1972); Philip Showalter Hench (1896-1965); and Tadeus Reichstein (1897-1996). Lancet 1999; 353: 1370.

2. Greenspan F.S., Gardner D.G., Lewiński A. Endokrynologia ogólna i kliniczna. Wydawnictwo Czelej, Lublin 2004.

3. Mcllwain H.H. Glucocorticoid-induced osteoporosis: pathogenesis, diagnosis, and management. Prev. Med. 2003; 36: 243-249.

4. Gifford R.H. Corticosteroid therapy for rheumatoid arthritis. Med. Clin. North. Am. 1973; 57: 1179-1190.

5. Katz J.A. Treatment of inflammatory bowel disease with corticosteroids. Gastroenterol. Clin. North. Am. 2004; 33: 171-189.

6. Barnes P.J. Anti-inflammatory actions of glucocorticoids: molecular mechanisms. Clin. Sci. (Lonon) 1998; 94: 557-572.

7. Schacke H., Docke W.D., Asadullah K. Mechanisms involved in the side effects of glucocorticoids, Pharmacol. Ther. 2002; 96: 23-43.

8. Van Raalte D.H., Ouwens D.M., Diamant M. Novel insights into glucocorticoid-mediated diabetogenic effects: towards expansion of therapeutic options? Eur. J. Clin. Invest. 2009; 39: 81-93.

9. Walker B.R. Glucocorticoids and cardiovascular disease. Eur. J. Endocrinol. 2007; 157: 545-559.

10. Ingle D.J. The production of glycosuria in the normal rat by means of 17-hydroxy-dehydroxycorticosterone. Endocrinology 1941; 29: 649-657.

11. American Diabetes Association Diagnosis and Classification of Diabetes Mellitus Diabetes Care 2011; 34 (supl. 1): S62-S69.

12. Wami W.M., Buntinx F., Bartholomeeusenet S. i wsp. Influence of chronic comorbidity and medication on the efficacy of treatment in patients with diabetes in general practice $\mathrm{Br}$. J. Gen. Pract. 2013; 63: 267-273.

13. Rosmond R., Chagnon Y.C., Holm G. i wsp. A glucocorticoid receptor gene marker is associated with abdominal obesity, leptin, and dysregulation of the hypothalamic-pituitary-adrenal axis. Obes. Res. 2000; 8: 211-218.

14. Buemann B., Vohl M.C., Chagnon M. i wsp. Abdominal visceral fat is associated with a Bcll restriction fragment length polymorphism at the glucocorticosteroid receptor gene locus. Obes. Res. 1997; 5: 186-192.

15. Van Rossum E.F., Voorhoeve P.G., te Velde S.J. i wsp. The ER22/23EK polymorphism in the glucocorticoid receptor gene is associated with a beneficial body composition and muscle strength in young adults. J. Clin. Endocrinol. Metab. 2004; 89: 4004-4009.

16. Syed A.A., Irving J.A., Redfern C.P. i wsp.. Association of glucocorticoid receptor polymorphism A3669G in exon 9 beta with reduced central adiposity in women. Obesity 2006; 14 : 759-764.
17. Roth D., Milgrom M., Esquenazi V. i wsp. Posttransplant hyperglycemia. Increased incidence in cyclosporine-treated renal allograft recipients. Transplantation 1989; 47: 278-281.

18. Sumrani N.B., Delaney V., Ding Z.K. i wsp. Diabetes mellitus after renal transplantation in the cyclosporine era: an analysis of risk factors. Transplantation 1991; 51: 343-347.

19. Vesco L., Busson M., Bedrossian J., Bitker M.O., Hiesse C., Lang P. Diabetes mellitus after renal transplantation: characteristics, outcome, and risk factors. Transplantation 1996; 61: 1475-1478.

20. Kern W., Stange E.F., Fehm H.L., Klein H.H. Glucocorticoid-induced diabetes mellitus in gastrointestinal diseases. Zeitschrift Gastroenterologie 1999; supl. 1: 36-42.

21. Valderhaug T.G., Hjelmesæth J., Rollag H. i wsp. Reduced incidence of new-onset posttransplantation diabetes mellitus during the last decade. Transplantation 2007; 84: 1125-1130.

22. Bloom R.D., Crutchlow M.F. New-onset diabetes mellitus in the kidney recipient: diagnosis and management strategies. Clin. J. Am. Soc. Nephrol. 2008; 3 (supl. 2): S38-S48.

23. Marchetti P. New-onset diabetes after liver transplantation: from pathogenesis to management. Liver Transplantation 2005; 11 : 612-620.

24. Giannarelli R., Coppelli A., Boggi U. i wsp. New-onset diabetes after kidney transplantation. Diabetic Medicine 2005; 22: 1125-1126.

25. Gulliford M.C., Charlton J., Latinovic R. Risk of diabetes associated with prescribed glucocorticoids in a large population. Diabetes Care 2006; 29: 2728-2729.

26. Gurwitz J.H., Bohn R.L., Glynn R.J., Monane M., Mogun H., Avorn J. Glucocorticoids and the risk for initiation of hypoglycemic therapy. Arch. Intern. Med. 1994; 154: 97-101.

27. Blackburn D., Hux J., Mamdani M. Quantification of the risk of corticosteroid-induced diabetes mellitus among the elderly. J. Gen. Intern. Med. 2002; 17: 717-720.

28. Hoes J.N., van der Goes M.C., van Raalte D.H. i wsp. Glucose tolerance, insulin sensitivity and beta-cell function in patients with rheumatoid arthritis treated with or without low-to-medium dose glucocorticoids. Ann. Rheum. Dis. 2011; 70: 1887-1894.

29. Uzu T., Harada T., Sakaguchi M. i wsp. Glucocorticoid-induced diabetes mellitus: prevalence and risk factors in primary renal diseases. Nephron. Clin. Pract. 2007; 105: c54-c57.

30. Suissa S., Kezouh A., Ernst P. i wsp. Inhaled corticosteroids and the risks of diabetes onset and progression Am. J. Med. 2010; 123: 1001-1006.

31. O'Byrne P.M., Rennard S., Gerstein H. i wsp. Risk of new onset diabetes mellitus in patients with asthma or COPD taking inhaled corticosteroids. Respir. Med. 2012; 106: 1487-1493.

32. Van der Linden M.W., Penning-van Beest F.J., Nijsten T. i wsp. Topical corticosteroids and the risk of diabetes mellitus: a nested case-control study in the Netherlands. Drug Saf. 2009; 32: 527-537.

33. Goldzweig O., Carrasco R., Hashkes P.J. Systemic adverse events following intraarticular corticosteroid injections for the treatment of juvenile idiopathic arthritis: two patients with dermatologic adverse events and review of the literature. Semin. Arthritis Rheum. 2013: 43: 71-76.

34. Chadban S. New-onset diabetes after transplantation: should it be a factor in choosing an immunosuppressant regimen for kidney transplant recipients. Nephrology Dialysis. Transplantation 2008; 23: 1816-1818.

35. Clore J.N., Thurby-Hay L. Glucocorticoid-induced hyperglycemia. Endocrine Practice 2009; 15: 469-474.

36. Jeong I.K., Oh S.H., Kim B.J. i wsp. The effects of dexamethasone on insulin release and biosynthesis are dependent on the dose and duration of treatment. Diabetes Res. Clin. Practice 2001; 51 163-171.

37. Ariza-Andraca C.R., Barile-Fabris L.A., Frati-Munari A.C., Baltazar-Montufar P. Risk factors for steroid diabetes in rheumatic patients. Arch. Med. Res. 1998; 29: 259-226.

38. Iwamoto T., Kagawa Y., Naito Y., Kuzuhara S., Kojima M. Steroid-induced diabetes mellitus and related risk factors in patients with neurologic diseases. Pharmacotherapy 2004; 24: 508-514. 
39. Arner P. Gunnarsson R., Blomdahl S., Groth C.G. Some characteristics of steroid diabetes: a study in renal-transplant recipients receiving high-dose corticosteroid therapy. Diabetes Care 1983; 6: 23-25.

40. Van Raalte D.H., Brands M., van der Zijl N.J. i wsp. Low-dose glucocorticoid treatment affects multiple aspects of intermediary metabolism in healthy humans: a randomised controlled trial. Diabetologia 2011; 54: 2103-2112.

41. Kalhan S.C., Adam P.A. Inhibitory effect of prednisone on insulin secretion in man: model for duplication of blood glucose concentration. J. Clin. Endocrinol. Metab. 1975; 41: 600-610.

42. Van Raalte D.H., Nofrate V., Bunck M.C. i wsp. Acute and 2-week exposure to prednisolone impair different aspects of beta-cell function in healthy men. Eur. J. Endocrinol. 2010; 162: 729-735.

43. Lambillotte C., Gilon P., Henquin J.C. Direct glucocorticoid inhibition of insulin secretion. An in vitro study of dexamethasone effects in mouse islets. J. Clin. Invest. 1997; 99: 414-423.

44. Van Raalte D.H., Ouwens D.M., Diamant M. Novel insights into glucocorticoid-mediated diabetogenic effects: towards expansion of therapeutic options? Eur. J. Clin. Invest. 2009; 39: 81-93.

45. Linssen M.M., van Raalte D.H., Toonen E.J. i wsp. Prednisolone-induced beta cell dysfunction is associated with impaired endoplasmic reticulum homeostasis in INS-1E cells. Cell Signal 2011; 23: 1708-1715.

46. Longano C.A., Fletcher H.P. Insulin release after acute hydrocortisone treatment in mice. Metabolism 1983; 32: 603-608.

47. Plat L., Byrne M.M., Sturis J. i wsp. Effects of morning cortisol elevation on insulin secretion and glucose regulation in humans. Am. J. Physiol. Endocrinol. Metab. 1996; 270: E36-E42.

48. Wise J.K., Hendler R., Felig P. Influence of glucocorticoids on glucagon secretion and plasma amino acid concentrations in man. J. Clin. Invest. 1973; 52: 2774-2782.

49. Zhang R., Packard B.A., Tauchi M. i wsp. Glucocorticoid regulation of preproglucagon transcription and RNA stability during stress. Proc. Natl. Acad. Sci. USA 2009; 106: 5913-5918.

50. Hansen K.B., Vilsboll T., Bagger J.I. i wsp. Reduced glucose tolerance and insulin resistance induced by steroid treatment, relative physical inactivity, and high-calorie diet impairs the incretin effect in healthy subjects. J. Clin. Endocrinol. Metab. 2010; 95: 3309-3317.

51. Hansen K.B., Vilsboll T., Bagger J.I. i wsp. Increased postprandial GIP and glucagon responses, but unaltered GLP-1 response after intervention with steroid hormone, relative physical inactivity, and high-calorie diet in healthy subjects. J. Clin. Endocrinol. Metab. 2011; 96: 447-453.

52. Van Raalte D.H., Kwa K.A., van Genugten R.E. i wsp. Islet-cell dysfunction induced by glucocorticoid treatment: potential role for altered sympathovagal balance? Metabolism 2013; 62: 568-577.

53. Hansen K.B., Vilsboll T., Bagger J.I., Holst J.J., Knop F.K. Impaired incretin-induced amplification of insulin secretion after glucose homeostatic dysregulation in healthy subjects. J. Clin. Endocrinol. Metab. 2012: 97: 1363-1370.

54. Jensen D.H., Aaboe K., Henriksen J.E. i wsp. Steroid-induced insulin resistance and impaired glucose tolerance are both associated with a progressive decline of incretin effect in first-degree relatives of patients with type 2 diabetes. Diabetologia 2012; 55: 1406-1416.

55. Rose A.J., Vagiopoulos A., Herzig S. Role of glucocorticoids and the glucocorticoid receptor in metabolism: insights from genetic manipulations. J. Steroid. Biochem. Mol. Biol. 2010; 122: 10-20.
56. Poprzezińska J., Krzyżanowska-Świniarska B., Mizagowski T., Ziemak J., Widecka K. Metaboliczna otyłość u osób z prawidłową masą ciała a 11 beta-dehydrogenaza hydroksysteroidowa typu 1 (11beta-HSD1). Endokrynologia, Otyłość Zaburzenia Przemiany Materii 2009; 2: 73-80.

57. Yuen K.C.J., McDaniel P.A., Riddle M.C. Twenty-four-hour profiles of plasma glucose, insulin, C-peptide and free fatty acid in subjects with varying degrees of glucose tolerance following short-term, medium-dose prednisone (20 mg/day) treatment: evidence for differing effects on insulin secretion and action. Clin. Endocrinol. 2012; 77: 224-232.

58. Habib G.S., Bashir M., Jabbour A. Increased blood glucose levels following intra-articular injection of methylprednisolone acetate in patients with controlled diabetes and symptomatic osteoarthritis of the knee. Ann. Rheum. Dis. 2008; 67: 1790-1791.

59. Habib G., Safia A. The effect of intra-articular injection of beta-methasone acetate/betamethasone sodium phosphate on blood glucose levels in controlled diabetic patients with symptomatic osteoarthritis of the knee. Clin. Rheumatol. 2009; 28: 85-87.

60. Habib G.S., Abu-Ahmad R. Lack of effect of corticosteroid injection at the shoulder joint on blood glucose levels in diabetic patients. Clin. Rheumatol. 2007; 26: 566-568.

61. Younes M., Neffati F., Touzi M. i wsp.. Systemic effects of epidural and intra-articular glucocorticoid injections in diabetic and non-diabetic patients. Joint Bone Spine 2007; 74: 472-476.

62. Even J.L., Crosby C.G., Song Y. Effects of epidural steroid injections on blood glucose levels in patients with diabetes mellitus. Spine J. 2012; 37: E46-E50.

63. Gonzalez P., Laker S.R., Sullivan W., Harwood J.E., Akuthota V. The effects of epidural betamethasone on blood glucose in patients with diabetes mellitus. PMR 2009; 1: 340-345.

64. Morita H., Oki Y., Ito T. i wsp. Administration of troglitazone, but not pioglitazone, reduces insulin resistance caused by short-term dexamethasone (DXM) treatment by accelerating the metabolism of DXM. Diabetes Care 2001; 24: 788-789.

65. Willi S.M., Kennedy A., Wallace P. i wsp. Troglitazone antagonizes metabolic effects of glucocorticoids in humans: effects on glucose tolerance, insulin sensitivity, suppression of free fatty acids, and leptin. Diabetes 2002; 51: 2895-2902.

66. Clore J.N., Thurby-Hay L. Glucocorticoid-induced hyperglycemia. Endocr. Pract. 2009; 15: 469-474.

67. Ritzel R.A., Kleine N., Holst J.J. i wsp. Preserved GLP-1 effects in a diabetic patient with Cushing's disease. Exp. Clin. Endocrinol. Diabetes 2007; 115: 146-150.

68. Matsuo K., Nambu T., Matsuda Y. i wsp. Evaluation of the effects of exenatide administration in patients with type 2 diabetes with worsened glycemic control caused by glucocorticoid therapy. Intern. Med. 2013; 52: 89-95.

69. Van Raalte D.H., van Genugten R.E., Linssen M.M. i wsp. Glucagon-like peptide-1 receptor agonist treatment prevents glucocorticoid-induced glucose intolerance and islet-cell dysfunction in humans. Diabetes Care 2011; 34: 412-417.

70. Yanai H., Masui Y., Yoshikawa R. i wsp. Dipeptidyl peptidase-4 inhibitor for steroid-induced diabetes. World J. Diabetes 2010; 1: 99-100.

71. Ohashi N., Tsuji N., Naito Y. i wsp. Alogliptin improves steroid-induced hyperglycemia in treatment-naïve Japanese patients with chronic kidney disease by decrease of plasma glucagon levels. Med. Sci. Monit. 2014; 20: 587-593.

72. Wierusz-Wysocka B., Zozulińska-Ziółkiewicz D. Postępowania w stanach nagłych i szczególnych u chorych na cukrzycę. Wyd. I. Via Medica, Gdańsk 2009. 